\title{
The relationship between passion, planning, goal setting, target achievement and sustainable supply chain in food industry
}

\author{
Anchalee Hiranphaet ${ }^{\mathrm{a}}$, Tommanee Suksai ${ }^{\mathrm{a}}$, Karnnapat Chumkad ${ }^{\mathrm{a}}$, Ratchaneewan Sujarita ${ }^{\mathrm{a}}$ Pongtep \\ Phudetch $^{\mathrm{a}}$, Sirion Son-ong ${ }^{\mathrm{a}}$, Ronnakorn Vaiyavuth ${ }^{\mathrm{b}}$, Kittisak Jermsittiparsert ${ }^{\mathrm{c}}$ and Rungkarn Siliboon ${ }^{\mathrm{d}}$
}

${ }^{a}$ College of Logistics and Supply Chain, Suansunandha Rajabhat University, Thailand

${ }^{b}$ Chulalongkorn School of Integrated Innovation, Chulalongkorn University, Thailand

${ }^{c}$ College of Innovative Business and Accountancy, Dhurakij Pundit University, Thailand

${ }^{d}$ Kasco It Co., Ltd., Thailand

\section{A B S T R A C T}

Article history:
Received September 19, 2021
Received in revised format
October 24, 2021
Accepted November 272021
Available online
November 272021
Keywords:
Passion
Planning
Goal Setting
Target Achievement
Sustainable Supply Chain
Food Industry

\begin{abstract}
Food industry has vital importance globally in which supply chain sustainability plays a key role. Therefore, the objective of this study is to examine the role of passion, planning, goal setting and target achievement in a sustainable supply chain. This study examined the relationship between passion, planning, goal setting, target achievement and sustainable supply chain among the food industry of Indonesia. Questionnaire survey was preferred, and 500 questionnaires were used for data collection. Findings of the study concluded that passion has a positive role in target achievement and an insignificant effect on sustainable supply chain. Planning has a positive effect on target achievement and sustainable supply chain. Moreover, goal setting has a positive role in target achievement and no role in supply chain. Furthermore, target achievement has a significant mediating role. Finally, the relationship between passion, planning, goal setting, target achievement and sustainable supply chain has valuable contributions to the literature.
\end{abstract}

C) 2022 Growing Science Ltd. All rights reserved.

\section{Introduction}

Dependency on supply chain activities is increasing among companies because supply to the companies and from the companies to outside stakeholders is most important. In both cases, the supply is important for the internal stakeholders of the company and external stakeholders. In case of internal stakeholders, supply of material is required for the manufacturing of goods. Timely manufacturing of goods is most important among the companies. In case of external stakeholders, the supply of goods to the suppliers and customers is most important. Internal supply is connected with external supply of goods because timely supply of material to the companies is required to fulfill the demand of external stakeholders. Therefore, supply chain activities have major concerns among the companies (Ul-Hameed, Mohammad, Shahar, Aljumah, \& Azizan, 2019). Better supply among the companies is responsible for better performance of company's timely management of supply chain activities is the guarantee of better operations related to the supply chain which causes to increase the performance. Among all other factors of a company's performance, supply chain has a major role. Performance of company supply chain activities should have sustainability. Companies require consistent supply chain accuracy to enhance the performance of a company. Therefore, sustainability in the supply chain activities is required. To achieve the highest performance, sustainability in the supply chain is required. Increase or decrease in the supply chain performance of companies cannot achieve the highest performance. Number of previous investigations supported the importance of sustainable supply chain among different companies (Lim, Tseng, Tan, \& Bui, 2017; Raut, Narkhede, \& Gardas, 2017; Somjai \& Jermsittiparsert, 2019; Jermsittiparsert, 2021). Therefore, the current study is also dealing with sustainable supply chain activities. This sustainability in the supply chain is also required in food supply companies. Food supply companies have a major role to * Corresponding author

E-mail address: kittisak.jer@dpu.ac.th (K. Jermsittiparsert)

(C) 2022 Growing Science Ltd. All rights reserved.

doi: $10.5267 /$ j.uscm.2021.11.010 
play in the community which requires an active and consistent supply chain. Food industry has a significant contribution globally. It has vital importance in every country because these companies are dealing with the basic products required for the people to survive. Most importantly, these companies deal with the perishable products which have a few days life and require quick delivery to the customers. Therefore, in these companies, fast supply chain activities are required to handle food products. These products involve fruits as well as vegetables. These fruits and vegetables have a few days life therefore, a fast supply chain is required for these products to deliver from one point to another point. Therefore, the supply chain in the food industry is quite important as compared to the other industries (Bettín-Díaz, Rojas, \& Mejía-Moncayo, 2018; Chen, Liu, \& Oderanti, 2020). Along with the other countries, the food supply chain is most important in Indonesia. Indonesia is one of the countries with a huge population which requires a heavy amount of food supply on a daily basis. In this case, food supply is most important in Indonesia to fulfill the requirements of the country. Therefore, in Indonesia, supply chain sustainability is most important which requires quick supply chain activities. The Indonesian food industry is one of the widespread industries. It has a significant effect on the total exports of Indonesia. Therefore, it also has vital importance for Indonesia to export as well as other activities related to the various other countries. Therefore, this industry produces high revenue for Indonesia and contributes to the economic development.

The sustainable supply chain in the food industry of Indonesia can be achieved with the help of various factors. The focus of Indonesian food industry management on key areas can handle the issues in the food supply chain. The first key area is passion which is required among the employees of the food industry. As the significant level of passion among the company employees has the ability to increase sustainability in the supply chain. Passion is always important to achieve various objectives (Altaf, Hameed, Nadeem, \& Arfan, 2019). Second, planning is also an important element of the food supply chain. Proper planning by the food supply companies in the supply chain has the potential to enhance target achievement which leads to sustainability in the supply chain. The third element is goal setting which is also important for employees. Goal setting is vital among all the activities of the company including supply chain. Therefore, passion among employees, planning and goal setting has a positive role in target achievement in food supply companies which causes an increased sustainable supply chain. Therefore, this study examined the relationship between passion, planning, goal setting, target achievement and sustainable supply chain among the food industry of Indonesia. The objective of this study is to examine the role of passion, planning, goal setting and target achievement in a sustainable supply chain. Furthermore, the mediation effect of target achievement is also examined. Number of studies have examined the sustainable supply chain (Mardani et al., 2020; Yadav, Luthra, Jakhar, Mangla, \& Rai, 2020), however, literature have not examined the effect of passion, planning, goal setting and target achievement on sustainable supply chain among the food supply companies of Indonesia. Furthermore, previous studies also did not examine the mediation effect of target achievement in relation to the passion, planning, goal setting, target achievement and sustainable supply chain in food supply companies. Therefore, this study has a unique contribution to the literature along with practices. The relationship between passion, planning, goal setting, target achievement and sustainable supply chain among the food industry of Indonesia is given in Fig. 1.

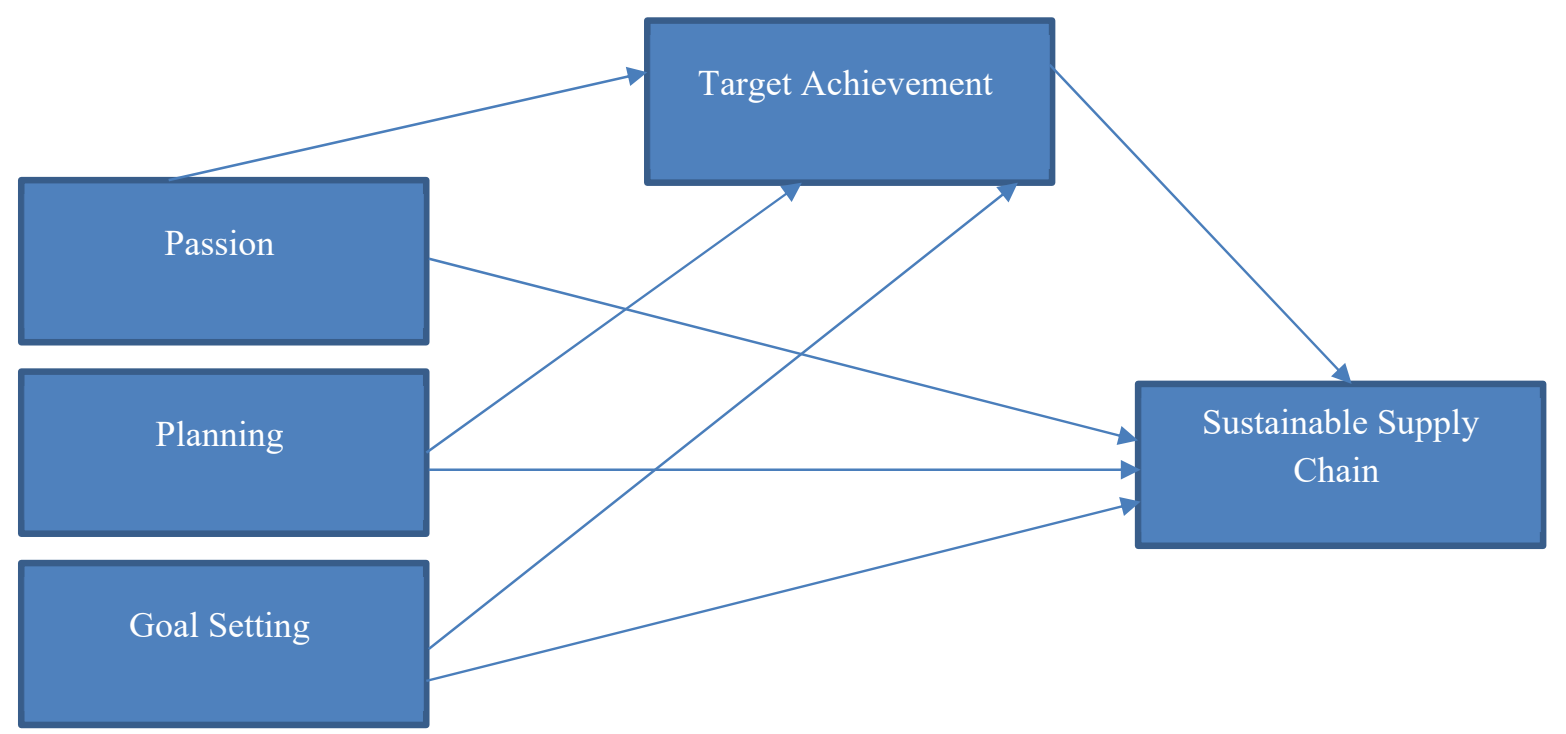

Fig. 1. Theoretical framework of the study showing the relationship between passion, planning, goal setting, target achievement and sustainable supply chain among the food industry of Indonesia

\section{Literature Review}




\subsection{Passion, Target Achievement and Sustainable Supply Chain}

Passion is a sensation of strong enthusiasm towards or convincing want for someone or something. Moreover, passion can range from keen attention to or appreciation for an idea, suggestion, or cause; to excited enjoyment of an interest as well as activity; to strong attraction, enthusiasm, or feeling towards a person. The passion among the employees of food companies has an important role. Particularly, it has an important role in the target achievement of these companies. A passionate employee always works hard to achieve the targets. Passion is a vital force which has a major role in target achievement. Generally, passion among the employees has a positive role in target achievement. As passion has the ability to increase performance (Clohessy, Whelan, \& Paradis, 2020; Huéscar Hernández, Moreno-Murcia, Cid, Monteiro, \& Rodrigues, 2020; Pan et al., 2020) which further increases the target achievement. Furthermore, passion among supply chain employees causes an increase in the satisfaction level which shows a positive role in target achievement. Furthermore, target achievement also shows the positive role in the supply chain. Target achievement is a vital element which shows a positive role. Passion increases the target achievement which further increases the supply chain. Hence, this discussion lead to the following hypotheses;

Hypothesis 1. Passion has a positive effect on target achievement.

Hypothesis 2. Passion has a positive effect on a sustainable supply chain.

\subsection{Planning, Target Achievement and Sustainable Supply Chain}

Planning is the procedure of thinking related to the actions obligatory to attain a desired objective. It is the very first as well as foremost action to attain desired results. It comprises the creation as well as preservation of a plan, such as psychological features that need conceptual skills. Planning has a vital role in any business activity. Better planning always leads to success; however, inappropriate planning has a negative role in business performance. As there is a connection between planning and performance (Domellöf et al., 2020). Better planning by the various companies has a relationship with the target achievement. As every company has a significant role in planning which has an effect on target achievement. Target achievement is handled by the various valuable planning by the employees. Better planning by the employee has the ability to achieve the targets of the company. Generally, companies first make the objectives and then make the planning. The target achievement is majorly based on the planning activities of the company. As in literature, there is a relationship between planning, target achievement and objectives (Magris, Pressey, Mills, Vila-Nova, \& Floeter, 2017; Robèrt, 2017). Furthermore, planning has a vital role in the supply chain among the food supply companies of Indonesia. Better planning by the employees has the ability to enhance the supply chain. Hence, following hypothesis is proposed;

Hypothesis 3. Planning has a positive effect on target achievement.

Hypothesis 4. Planning has a positive effect on a sustainable supply chain.

\subsection{Goal Setting, Target Achievement and Sustainable Supply Chain}

Goal setting includes the growth of an action plan intended to inspire as well as lead a person or group of persons toward a main goal. Goal setting could be directed by goal-setting standards such as criteria for the performance achievement. Goal setting is a main section of personal development as well as management literature. The importance of goal setting among the business cannot be neglected (Huis, Hansen, Otten, \& Lensink, 2019). Because goal setting has a vital role among the business activities to achieve the performance. Better goal setting by the employee has the ability to enhance the performance of various activities within the company. Especially, among the food supply companies of Indonesia, goal setting is most important which has a relationship with target achievement. Goal setting is also one of the points of planning. Both planning and goal setting have relationships (Kroll et al., 2019; Lenzen et al., 2018). Furthermore, target achievement has an effect on the supply chain. Any change in the goal setting in relation to the target achievement has a significant effect on the supply chain.

Hypothesis 5. Goal setting has a positive effect on target achievement. Hypothesis 6. Goal setting has a positive effect on a sustainable supply chain.

\subsection{Target Achievement and Sustainable Supply Chain}

Target is the set of limitations in which the major objective will be achieved by the management of the company. In the food supply companies, target achievement has a major role in various activities. A personal achievement is an attribute that provides an individual with a sense of pride. Target achievement has an important role in supply chain activities. Better target achievement can increase the effectiveness of work. If the employee has not set the objectives, they cannot perform better in this situation. Therefore, target achievement among the food supply companies has the most important role. Target achievement is the major concern of the companies (Kumalasari, Novia, Agusti, \& Anjarwi, 2019; Razzaq, Maqbool, \& 
Hameed, 2019) which causes an increase in the performance. Therefore, target achievement plays a mediating role between various factors. The mediation effect hypotheses are as follows;

Hypothesis 7. Target achievement has a positive effect on a sustainable supply chain.

Hypothesis 8. Target achievement mediates the relationship between passion and sustainable supply chain.

Hypothesis 9. Target achievement mediates the relationship between planning and sustainable supply chain.

Hypothesis 10. Target achievement mediates the relationship between goal setting and sustainable supply chain.

\section{Research Methodology}

To examine the relationship among different variables requires a quantitative or qualitative research approach. Both research approaches are recommended by the previous studies. The selection of the most appropriate technique is very important in any research study. This study is based on primary data analysis with the help of a survey instrument. Therefore, in the current study quantitative research approach is suitable rather than qualitative research approach. This study selected a quantitative approach because various previous studies also used a quantitative research approach in supply chain studies (Singsa, Sriyakul, Sutduean, \& Jermsittiparsert, 2019). Hence, by following the previous investigation, the current study selected a quantitative research approach to investigate the effect of passion, planning, goal setting and target achievement on a sustainable supply chain. Finally, to investigate the relationship between passion, planning, goal setting, target achievement and sustainable supply chain, this study designed a survey questionnaire with the help of previous studies. The measures for all variables were taken from the previous studies to design survey instruments. Finally, after development of scale, the questionnaires were distributed among the Indonesian food supply companies. Thus, the population of the current study is food supply companies from Thailand. Questionnaire survey was preferred, and 500 questionnaires were used for data collection. 231 questionnaires were received for data analysis. Simple random sampling was used for questionnaire distribution in food supply companies (Kaur, Patil, Shirk, \& Taillie, 1996). Likert scale was applied in the current study for the collection of data and development of survey instruments. Likert scale was preferred in this study because this scale is appropriate for data collection from the employees of food supply companies.

\section{Research Findings}

Errors in the data related to the missing value (Aydin \& ŞENOĞLU, 2018) has reasonable effects on the results of the data analysis. Therefore, to detect the missing value in the data, this study carried out preliminary data analysis as shown in Table 1.

Table 1

Data Statistics

\begin{tabular}{|c|c|c|c|c|c|c|c|c|c|}
\hline & No. & Missing & Mean & Median & Min & Max & SD & Kurtosis & Skewness \\
\hline PASS1 & 1 & 0 & 3.389 & 3 & 1 & 7 & 1.951 & -0.838 & 0.42 \\
\hline PASS2 & 2 & 0 & 3.349 & 3 & 1 & 7 & 2.117 & -1.145 & 0.412 \\
\hline PASS3 & 3 & 0 & 3.403 & 3 & 1 & 7 & 2.149 & -1.15 & 0.414 \\
\hline PASS4 & 4 & 0 & 3.362 & 3 & 1 & 7 & 1.987 & -1.057 & 0.39 \\
\hline PLANN1 & 5 & 0 & 3.403 & 3 & 1 & 7 & 1.914 & -0.793 & 0.45 \\
\hline PLANN2 & 6 & 0 & 3.181 & 3 & 1 & 7 & 1.939 & -0.851 & 0.444 \\
\hline PLANN3 & 7 & 0 & 3.315 & 3 & 1 & 7 & 2.05 & -1.012 & 0.393 \\
\hline PLANN4 & 8 & 0 & 3.248 & 3 & 1 & 7 & 1.952 & -1.022 & 0.373 \\
\hline GS1 & 9 & 0 & 2.966 & 2 & 1 & 7 & 2.196 & -0.738 & 0.845 \\
\hline GS2 & 10 & 0 & 2.785 & 2 & 1 & 7 & 2.191 & -0.613 & 0.924 \\
\hline GS3 & 11 & 0 & 3.054 & 2 & 1 & 7 & 2.167 & -0.818 & 0.766 \\
\hline GS4 & 12 & 0 & 2.94 & 2 & 1 & 7 & 2.168 & -0.719 & 0.841 \\
\hline TA1 & 13 & 0 & 2.872 & 2 & 1 & 7 & 2.35 & -0.872 & 0.885 \\
\hline TA2 & 14 & 0 & 2.745 & 2 & 1 & 7 & 2.04 & -0.192 & 1.059 \\
\hline TA3 & 15 & 0 & 2.94 & 2 & 1 & 7 & 1.97 & -0.486 & 0.829 \\
\hline TA4 & 16 & 0 & 2.832 & 2 & 1 & 7 & 1.905 & -0.166 & 0.931 \\
\hline TA5 & 17 & 0 & 2.779 & 2 & 1 & 7 & 2.072 & -0.384 & 0.963 \\
\hline TA6 & 18 & 0 & 2.792 & 2 & 1 & 7 & 1.998 & -0.36 & 0.923 \\
\hline TA7 & 19 & 0 & 3.034 & 2 & 1 & 7 & 2.28 & -0.918 & 0.778 \\
\hline SSC1 & 20 & 0 & 2.879 & 2 & 1 & 7 & 2.308 & -0.823 & 0.867 \\
\hline $\mathrm{SSC} 2$ & 21 & 0 & 2.698 & 2 & 1 & 7 & 2.032 & -0.14 & 1.076 \\
\hline SSC3 & 22 & 0 & 2.886 & 2 & 1 & 7 & 2.169 & -0.545 & 0.993 \\
\hline SSC4 & 23 & 0 & 3.51 & 4 & 1 & 6 & 1.527 & -1.079 & 0.055 \\
\hline SSC5 & 24 & 0 & 3.416 & 4 & 1 & 6 & 1.754 & -1.456 & -0.036 \\
\hline SSC6 & 25 & 0 & 3.45 & 3 & 1 & 6 & 1.603 & -1.321 & -0.041 \\
\hline SSC7 & 26 & 0 & 3.45 & 3 & 1 & 6 & 1.595 & -1.42 & -0.013 \\
\hline SSC8 & 27 & 0 & 3.376 & 3 & 1 & 6 & 1.645 & -1.51 & -0.226 \\
\hline
\end{tabular}

Note: PASS = Passion; PLANN = Planning; GS = Goal Setting; TA = Target Achievement; SSC = Sustainable Supply Chain 
According to the literature, confirmatory factor analysis (CFA) with the help of Partial Least Square (PLS) is most effective to examine factor loadings (F. Hair Jr, Sarstedt, Hopkins, \& G. Kuppelwieser, 2014; J. Hair, Hollingsworth, Randolph, \& Chong, 2017; J. F. Hair, Ringle, \& Sarstedt, 2013; J. F. Hair, Sarstedt, Pieper, \& Ringle, 2012; Henseler, Ringle, \& Sarstedt, 2015). Fig. 2 shows that passion is measured by using four items, planning was measured by using four items and goal setting is measured by using four items. Target achievement was measured through seven items and finally, sustainable supply chain was measured by using eight items. Therefore, all the constructs; passion, planning, goal setting, target achievement and sustainable supply chain have scale items above 0.7 .

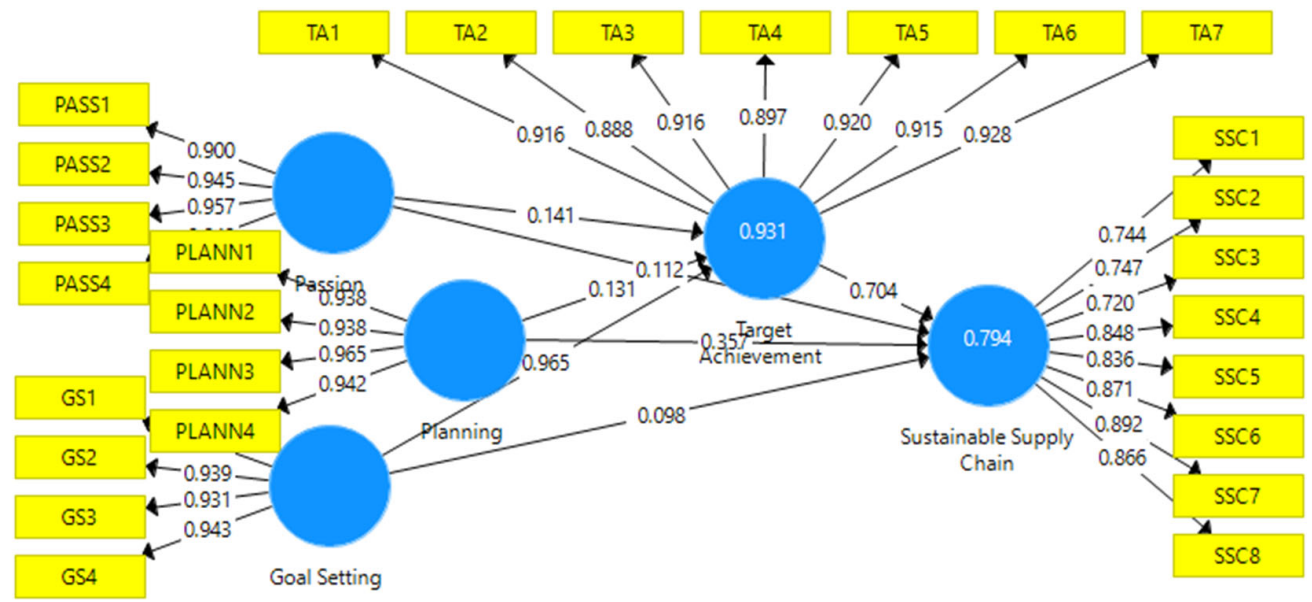

Fig. 2. Measurement Model

Table 2

Factor Loadings

\begin{tabular}{|c|c|c|c|c|c|}
\hline & Goal Setting & Passion & Planning & Sustainable Supply Chain & Target Achievement \\
\hline GS1 & 0.919 & & & & \\
\hline GS2 & 0.939 & & & & \\
\hline GS3 & 0.931 & & & & \\
\hline GS4 & 0.943 & & & & \\
\hline PASS1 & & 0.9 & & & \\
\hline PASS2 & & 0.945 & & & \\
\hline PASS3 & & 0.957 & & & \\
\hline PASS4 & & 0.949 & & & \\
\hline PLANN1 & & & 0.938 & & \\
\hline PLANN2 & & & 0.938 & & \\
\hline PLANN3 & & & 0.965 & & \\
\hline PLANN4 & & & 0.942 & & \\
\hline SSC1 & & & & 0.744 & \\
\hline $\mathrm{SSC} 2$ & & & & 0.747 & \\
\hline $\mathrm{SSC} 3$ & & & & 0.72 & \\
\hline $\mathrm{SSC} 4$ & & & & 0.848 & \\
\hline SSC5 & & & & 0.836 & \\
\hline SSC6 & & & & 0.871 & \\
\hline $\mathrm{SSC} 7$ & & & & 0.892 & \\
\hline SSC8 & & & & 0.866 & \\
\hline TA1 & & & & & 0.916 \\
\hline TA2 & & & & & 0.888 \\
\hline TA3 & & & & & 0.916 \\
\hline TA4 & & & & & 0.897 \\
\hline TA5 & & & & & 0.92 \\
\hline TA6 & & & & & 0.915 \\
\hline TA7 & & & & & 0.928 \\
\hline
\end{tabular}

Note: PASS = Passion; PLANN = Planning; GS = Goal Setting; TA = Target Achievement; SSC = Sustainable Supply Chain

Reliability, convergent validity and discriminant validity are the most influential part of data analysis. Analysis cannot be proceeded further without the achievement of reliability, convergent validity and discriminant validity. Therefore, to achieve reliability and validity CFA was examined as the results are given in Table 3. It is found that composite reliability (CR) for passion, planning, goal setting, target achievement and sustainable supply chain is above 0.7 . Moreover, it is given in Table 3 the average variance extracted (AVE) for passion, planning, goal setting, target achievement and sustainable supply chain is above 0.5 which achieved the convergent validity. Previous studies also recommended the minimum value for CR and AVE 0.7 and 0.5 , respectively. Further to this, the current study examined discriminant validity with cross-loadings as given in Table 4 (Fornell \& Larcker, 1981). 
Table 3

Reliability and Convergent Validity

\begin{tabular}{lllll}
\hline & Alpha & rho_A & CR & AVE \\
\hline Goal Setting & 0.95 & 0.951 & 0.964 & 0.871 \\
Passion & 0.954 & 0.954 & 0.967 & 0.88 \\
Planning & 0.961 & 0.963 & 0.972 & 0.895 \\
Sustainable Supply Chain & 0.928 & 0.928 & 0.941 & 0.972 \\
Target Achievement & 0.966 & 0.966 & 0.831 \\
\hline
\end{tabular}

Note: PASS = Passion; PLANN = Planning; GS = Goal Setting; TA = Target Achievement; SSC = Sustainable Supply Chain

Table 4

Cross-Loadings

\begin{tabular}{|c|c|c|c|c|c|}
\hline & Goal Setting & Passion & Planning & Sustainable Supply Chain & Target Achievement \\
\hline GS1 & 0.919 & 0.305 & 0.312 & 0.685 & 0.909 \\
\hline GS2 & 0.939 & 0.356 & 0.377 & 0.715 & 0.906 \\
\hline GS3 & 0.931 & 0.346 & 0.366 & 0.713 & 0.899 \\
\hline GS4 & 0.943 & 0.396 & 0.403 & 0.73 & 0.882 \\
\hline PASS1 & 0.344 & 0.9 & 0.871 & 0.617 & 0.316 \\
\hline PASS2 & 0.35 & 0.945 & 0.883 & 0.605 & 0.323 \\
\hline PASS3 & 0.333 & 0.957 & 0.856 & 0.591 & 0.305 \\
\hline PASS4 & 0.382 & 0.949 & 0.841 & 0.601 & 0.337 \\
\hline PLANN1 & 0.374 & 0.842 & 0.938 & 0.658 & 0.364 \\
\hline PLANN2 & 0.403 & 0.895 & 0.938 & 0.657 & 0.378 \\
\hline PLANN3 & 0.386 & 0.88 & 0.965 & 0.668 & 0.383 \\
\hline PLANN4 & 0.31 & 0.864 & 0.942 & 0.616 & 0.3 \\
\hline SSC1 & 0.69 & 0.313 & 0.355 & 0.744 & 0.615 \\
\hline $\mathrm{SSC} 2$ & 0.882 & 0.338 & 0.362 & 0.947 & 0.874 \\
\hline SSC3 & 0.857 & 0.298 & 0.326 & 0.892 & 0.873 \\
\hline SSC4 & 0.411 & 0.641 & 0.678 & 0.848 & 0.437 \\
\hline SSC5 & 0.386 & 0.684 & 0.717 & 0.836 & 0.412 \\
\hline SSC6 & 0.435 & 0.636 & 0.698 & 0.871 & 0.463 \\
\hline SSC7 & 0.499 & 0.69 & 0.716 & 0.892 & 0.51 \\
\hline SSC8 & 0.461 & 0.674 & 0.707 & 0.866 & 0.476 \\
\hline TA1 & 0.888 & 0.331 & 0.353 & 0.755 & 0.916 \\
\hline TA2 & 0.848 & 0.234 & 0.256 & 0.676 & 0.888 \\
\hline TA3 & 0.882 & 0.337 & 0.368 & 0.71 & 0.916 \\
\hline TA4 & 0.886 & 0.293 & 0.325 & 0.683 & 0.897 \\
\hline TA5 & 0.872 & 0.344 & 0.381 & 0.734 & 0.92 \\
\hline TA6 & 0.889 & 0.291 & 0.328 & 0.668 & 0.915 \\
\hline TA7 & 0.882 & 0.345 & 0.395 & 0.762 & 0.928 \\
\hline
\end{tabular}

Note: PASS = Passion; PLANN = Planning; GS = Goal Setting; TA = Target Achievement; SSC = Sustainable Supply Chain

This section of the study is based on the testing relationships between variables. The effect of passion was examined on target achievement and supply chain. The effect of planning was examined on target achievement and supply chain. Moreover, the effect of goal setting was examined on target achievement and supply chain. Finally, the effect of target achievement was examined on the supply chain. The process was handled with the help of the PLS structural model (Henseler \& Chin, 2010; Henseler et al., 2014; Henseler, Ringle, \& Sinkovics, 2009; Iqbal \& Hameed, 2020). Results are given in Table 5 showing that passion has a positive effect on target achievement and an insignificant effect on the supply chain. Planning has a positive effect on both target achievement and supply chain. Goal setting has a positive effect on target achievement; however, it has an insignificant effect on the supply chain. Finally, it is found that target achievement has a positive effect on a sustainable supply chain. This process is given in Fig. 3 .

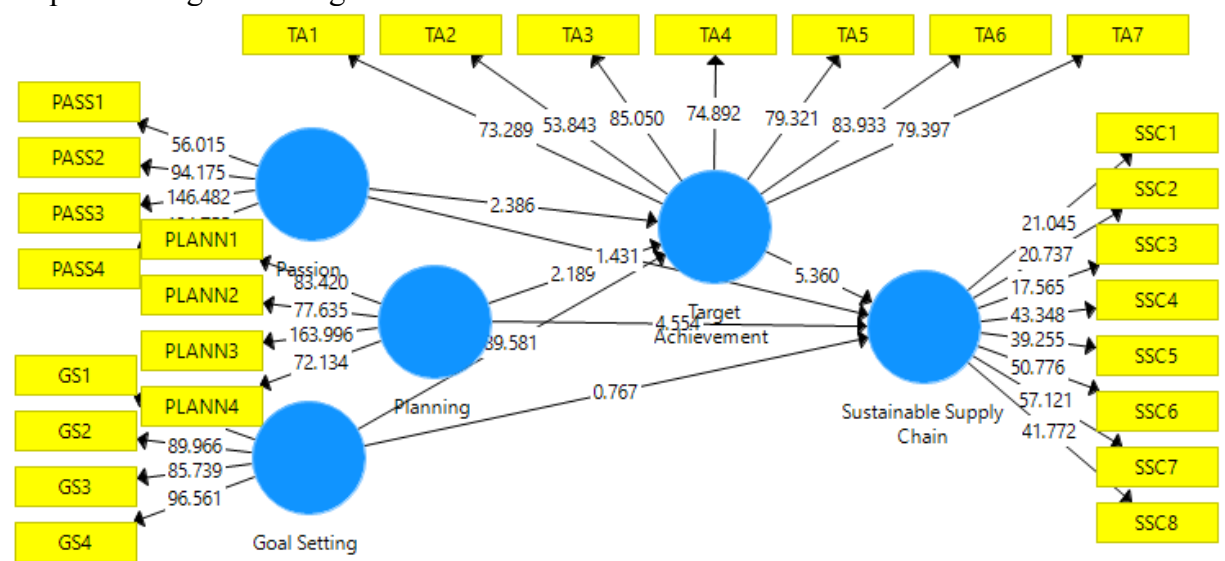

Fig. 3. Structural Model 
Table 5

Direct Effect Results

\begin{tabular}{|c|c|c|c|c|c|}
\hline & (O) & (M) & SD & T Statistics & P Values \\
\hline Goal Setting $\rightarrow$ Sustainable Supply Chain & 0.098 & 0.115 & 0.127 & 0.767 & 0.443 \\
\hline Goal Setting $\rightarrow$ Target Achievement & 0.965 & 0.966 & 0.011 & 89.581 & 0 \\
\hline Passion $\rightarrow$ Sustainable Supply Chain & 0.112 & 0.113 & 0.078 & 1.431 & 0.153 \\
\hline Passion $\rightarrow$ Target Achievement & 0.141 & 0.138 & 0.059 & 2.386 & 0.017 \\
\hline Planning $\rightarrow$ Sustainable Supply Chain & 0.357 & 0.361 & 0.078 & 4.554 & 0 \\
\hline Planning $\rightarrow$ Target Achievement & 0.131 & 0.127 & 0.06 & 2.189 & 0.029 \\
\hline Target Achievement $\rightarrow$ Sustainable Supply Chain & 0.704 & 0.717 & 0.131 & 5.36 & 0 \\
\hline
\end{tabular}

Note: PASS = Passion; PLANN = Planning; GS = Goal Setting; TA = Target Achievement; SSC = Sustainable Supply Chain

Indirect effect or meditation effect is given in Table 6. In this process, the mediation effect of target achievement was examined between passion and sustainable supply chain. The mediation effect of target achievement was also examined between planning and sustainable supply chain. Finally, the mediation effect of target achievement was examined between goal setting and sustainable supply chain. It is found that the mediation effect between passion and sustainable supply chain found t-value 2.226 which is significant, it is also given in Fig. 4. The mediation effect of target achievement between planning and sustainable supply chain found t-value 2.069 which is significant as shown in Fig. 5. Furthermore, the mediation effect of target achievement between goal setting and sustainable supply chain is also significant with t-value 5.368 which is shown in Fig. 6. Hence, these results show that target achievement reflects the positive effect of passion, planning and goal setting on a sustainable supply chain. This mediation effect was examined by considering the recommendations of Preacher and Hayes (2008).

Table 6

Indirect Effect Results

\begin{tabular}{|c|c|c|c|c|c|}
\hline & (O) & (M) & SD & T Statistics & P Values \\
\hline Goal Setting $\rightarrow$ Target Achievement $\rightarrow$ Sustainable Supply Chain & 0.679 & 0.693 & 0.127 & 5.368 & 0 \\
\hline Passion $\rightarrow$ Target Achievement $\rightarrow$ Sustainable Supply Chain & -0.099 & -0.098 & 0.045 & 2.226 & 0.026 \\
\hline Planning $\rightarrow$ Target Achievement $\rightarrow$ Sustainable Supply Chain & 0.092 & 0.09 & 0.044 & 2.069 & 0.039 \\
\hline
\end{tabular}

Note: PASS = Passion; PLANN = Planning; GS = Goal Setting; TA = Target Achievement; SSC = Sustainable Supply Chain

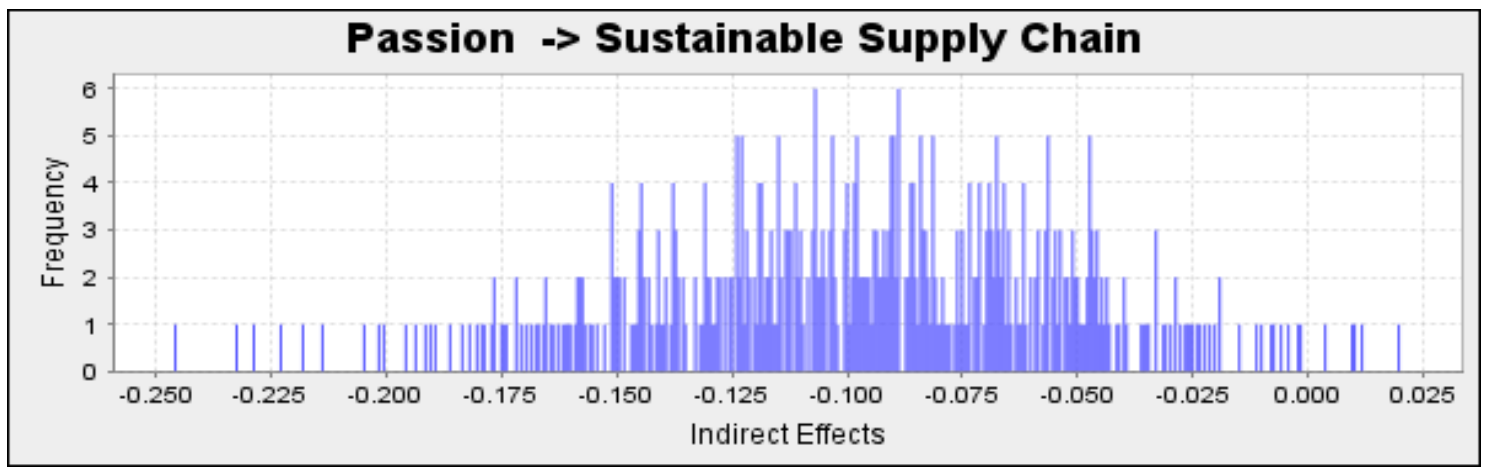

Fig. 4. Indirect Effect Histogram: Passion $\rightarrow$ Target Achievement $\rightarrow$ Sustainable Supply Chain

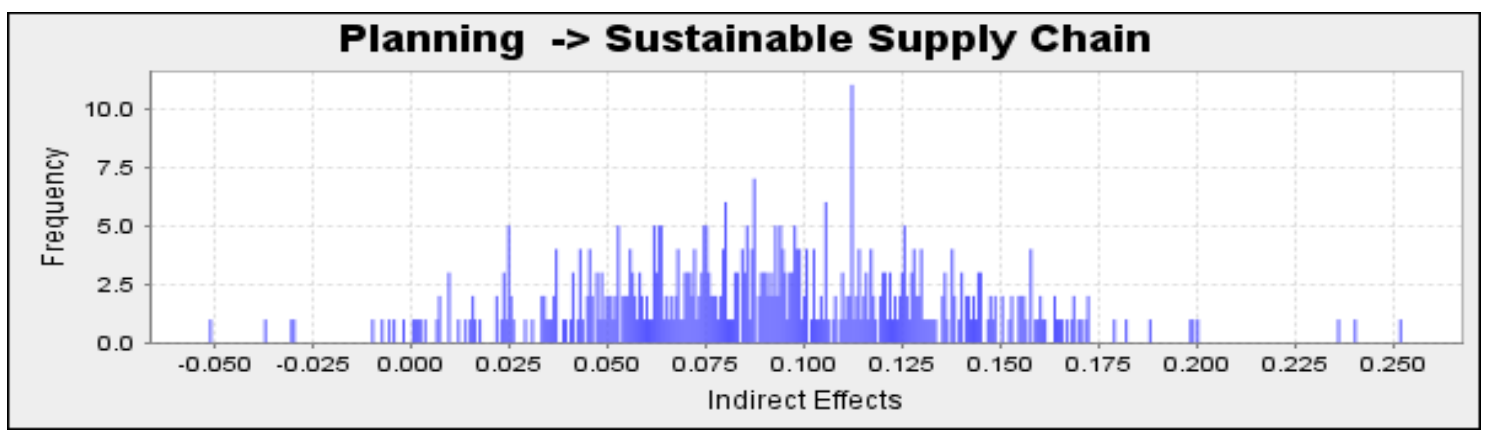

Fig. 5. Indirect Effect Histogram: Planning $\rightarrow$ Target Achievement $\rightarrow$ Sustainable Supply Chain 


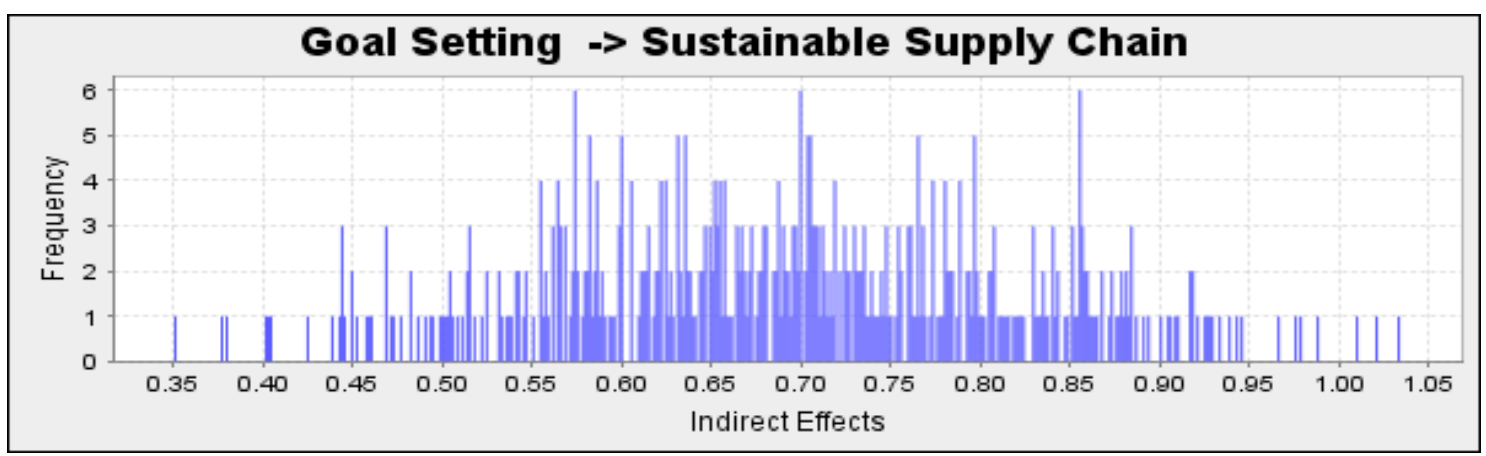

Fig. 6. Indirect Effect Histogram: Goal Setting $\rightarrow$ Target Achievement $\rightarrow$ Sustainable Supply Chain

After the analysis and examination of hypotheses results, the current study examined the variance explained in the sustainable supply chain. This variance was examined with the help of r-square value. The r-square value is 0.794 for the supply chain as shown in Fig. 2. It shows that all the variables; passion, planning, goal setting and target achievement has the potential to bring $79.4 \%$ in the supply chain which is strong (Chin, 1998).

\section{Conclusion}

The objective of this study was to examine the role of passion, planning, goal setting and target achievement in a sustainable supply chain. The relationship between passion, planning, goal setting, target achievement and sustainable supply chain among the food industry of Indonesia was examined with the help of collecting data from Indonesian food supply companies with the help of questionnaire surveys. Results of the findings shows that the supply chain is most important for the food supply companies. Literature also shows that a better supply chain of food supply companies has a major role in the daily activities of food supply in the whole country to fulfill the needs of people. Results of the study shows that passion of the employees have a positive role to enhance target achievement. Increase in the passion among the employees increases the target achievement. Moreover, planning has a positive effect on supply chain and target achievement. Better planning by the employee and management of food supply companies related to the food supply have a positive effect on supply chain and target achievement. Hence, improvement in planning activities improves the supply chain and target achievement. Furthermore, it is found that goal setting has a major contribution to target achievement, goal setting by the employee shows a positive role to improve target achievement efforts. Finally, target achievement has a positive effect on a sustainable supply chain. Therefore, passion, planning and goal setting has a positive effect on target achievement which further increases the sustainable supply chain in food supply companies of Indonesia.

\section{Implications of the Study}

The relationship between passion, planning, goal setting, target achievement and sustainable supply chain among the food industry of Indonesia which is examined in the current study has valuable contributions for literature. Because the effect of passion, planning and goal setting was not examined in relation to the target achievement. The effect of passion, planning and goal setting was not examined on the supply chain. Therefore, this is a unique relationship which has valuable contributions. Moreover, this valuable relationship was not previously examined among the food supply companies of Indonesia. Furthermore, this study also contributed by investigating the mediation effect of target achievement. The first mediation effect of target achievement was examined between passion and sustainable supply chain. The second mediation effect of target achievement was also examined between planning and sustainable supply chain. Finally, the third mediation effect of target achievement was examined between goal setting and sustainable supply chain. Practically, this study is valuable for food supply companies to enhance the supply chain in the food industry. This study suggested that food supply companies should enhance the supply chain with the help of passion, planning and goal setting.

\section{Limitations of the Study}

This study is limited to the Indonesian supply chain companies. The scope of study should be enhanced by involving other countries. The developing countries should be involved to examine the effect of passion, planning and goal setting on the supply chain. Developed countries have different food industries, therefore, it is suitable to include developing countries. Moreover, other variables should also include having an effect on the supply chain in food supply companies. Finally, the relationship between these variables is measured by using a survey questionnaire, however, this relationship can be better examined by taking interviews from the employees of food supply companies in Indonesia. Therefore, interviews should also be included in the current study to confirm the results obtained from the survey. 


\section{References}

Altaf, M., Hameed, W., Nadeem, S., \& Arfan, S. (2019). Successful Entrepreneurial Process as Contributor towards Business Performance in Banking: Moderating Role of Passion for Inventing. South Asian Journal of Management Sciences, 13(1), $13-40$.

Aydin, D., \& Şenoğlu, B. (2018). Estimating the Missing Value in One-Way Anova Under Long-Tailed Symmetric Error Distributions. Sigma: Journal of Engineering \& Natural Sciences/Mühendislik ve Fen Bilimleri Dergisi, 36(2).

Bettín-Díaz, R., Rojas, A. E., \& Mejía-Moncayo, C. (2018). Methodological approach to the definition of a blockchain system for the food industry supply chain traceability. Paper presented at the International Conference on Computational Science and Its Applications.

Chen, H., Liu, S., \& Oderanti, F. (2020). A knowledge network and mobilisation framework for lean supply chain decisions in agri-food industry Supply Chain and Logistics Management: Concepts, Methodologies, Tools, and Applications (pp. 369-381): IGI Global.

Chin, W. W. (1998). The partial least squares approach to structural equation modeling. Modern methods for business research, 295(2), 295-336.

Clohessy, T., Whelan, E., \& Paradis, K. F. (2020). Does passion for physical activity spillover into performance at work? Examining the direct and indirect effects of passion and life satisfaction on organisational performance and innovativeness. International journal of sport and exercise psychology, 1-21.

Domellöf, E., Bäckström, A., Johansson, A. M., Rönnqvist, L., von Hofsten, C., \& Rosander, K. (2020). Kinematic characteristics of second-order motor planning and performance in 6-and 10-year-old children and adults: Effects of age and task constraints. Developmental Psychobiology, 62(2), 250-265.

F. Hair Jr, J., Sarstedt, M., Hopkins, L., \& G. Kuppelwieser, V. (2014). Partial least squares structural equation modeling (PLS-SEM) An emerging tool in business research. European Business Review, 26(2), 106-121.

Fornell, C., \& Larcker, D. F. (1981). Evaluating structural equation models with unobservable variables and measurement error. Journal of marketing research, 39-50.

Hair, J., Hollingsworth, C. L., Randolph, A. B., \& Chong, A. Y. L. (2017). An updated and expanded assessment of PLSSEM in information systems research. Industrial Management \& Data Systems, 117(3), 442-458.

Hair, J. F., Ringle, C. M., \& Sarstedt, M. (2013). Partial least squares structural equation modeling: Rigorous applications, better results and higher acceptance.

Hair, J. F., Sarstedt, M., Pieper, T. M., \& Ringle, C. M. (2012). The use of partial least squares structural equation modeling in strategic management research: a review of past practices and recommendations for future applications. Long range planning, 45(5-6), 320-340.

Henseler, J., \& Chin, W. W. (2010). A comparison of approaches for the analysis of interaction effects between latent variables using partial least squares path modeling. Structural Equation Modeling, 17(1), 82-109.

Henseler, J., Dijkstra, T. K., Sarstedt, M., Ringle, C. M., Diamantopoulos, A., Straub, D. W., . . Calantone, R. J. (2014). Common beliefs and reality about PLS: Comments on Rönkkö and Evermann (2013). Organizational Research Methods, 17(2), 182-209.

Henseler, J., Ringle, C. M., \& Sarstedt, M. (2015). A new criterion for assessing discriminant validity in variance-based structural equation modeling. Journal of the academy of marketing science, 43(1), 115-135.

Henseler, J., Ringle, C. M., \& Sinkovics, R. R. (2009). The use of partial least squares path modeling in international marketing New challenges to international marketing (pp. 277-319): Emerald Group Publishing Limited.

Huéscar Hernández, E., Moreno-Murcia, J. A., Cid, L., Monteiro, D., \& Rodrigues, F. (2020). Passion or perseverance? The effect of perceived autonomy support and grit on academic performance in college students. International Journal of Environmental Research and Public Health, 17(6), 2143.

Huis, M. A., Hansen, N., Otten, S., \& Lensink, R. (2019). The impact of husbands' involvement in goal-setting training on women's empowerment: First evidence from an intervention among female microfinance borrowers in Sri Lanka. Journal of Community \& Applied Social Psychology, 29(4), 336-351.

Iqbal, J., \& Hameed, W. U. (2020). Open Innovation Challenges and Coopetition-Based Open-Innovation Empirical Evidence From Malaysia Innovative Management and Business Practices in Asia (pp. 144-166): IGI Global.

Jermsittiparsert, K. (2021). Role of Sustainable Supply Chain, Marketing Performance and Information Availability in Sustainable Business Performance. Journal of Management Information and Decision Sciences, 24(S1), 36.

Kaur, A., Patil, G., Shirk, S. J., \& Taillie, C. (1996). Environmental sampling with a concomitant variable: a comparison between ranked set sampling and stratified simple random sampling. Journal of applied statistics, 23(2-3), 231-256.

Kroll, S. A., Horwitz, R. J., Keller, D. H., Sweeney, B. W., Jackson, J. K., \& Perez, L. B. (2019). Large-scale protection and restoration programs aimed at protecting stream ecosystem integrity: the role of science-based goal-setting, monitoring, and data management. Freshwater Science, 38(1), 23-39.

Kumalasari, K. P., Novia, R., Agusti, R. R., \& Anjarwi, A. W. (2019). Analysis of the Monitoring Implementation of Public Road Parking Retribution toward the Target Achievement of Regional Expenditure Malang in 2017 (A study in technical implementary unit of kepanjen transportations department). Paper presented at the Annual International Conference of Business and Public Administration (AICoBPA 2018). 
Lenzen, S. A., Stommel, W., Daniëls, R., van Bokhoven, M. A., van der Weijden, T., \& Beurskens, A. (2018). Ascribing patients a passive role: conversation analysis of practice nurses' and patients' goal setting and action planning talk. Research in Nursing \& Health, 41(4), 389-397.

Lim, M. K., Tseng, M.-L., Tan, K. H., \& Bui, T. D. (2017). Knowledge management in sustainable supply chain management: Improving performance through an interpretive structural modelling approach. Journal of Cleaner Production, 162, 806816.

Magris, R. A., Pressey, R. L., Mills, M., Vila-Nova, D. A., \& Floeter, S. (2017). Integrated conservation planning for coral reefs: Designing conservation zones for multiple conservation objectives in spatial prioritisation. Global Ecology and Conservation, 11, 53-68.

Mardani, A., Kannan, D., Hooker, R. E., Ozkul, S., Alrasheedi, M., \& Tirkolaee, E. B. (2020). Evaluation of green and sustainable supply chain management using structural equation modelling: A systematic review of the state of the art literature and recommendations for future research. Journal of Cleaner Production, 249, 119383.

Pan, Z.-H., Ning, D.-S., Fu, Y.-X., Li, D.-P., Zou, Z.-Q., Xie, Y.-C., . . Li, L.-C. (2020). Preparative Isolation of Piceatannol Derivatives from Passion Fruit (Passiflora edulis) Seeds by High-Speed Countercurrent Chromatography Combined with High-Performance Liquid Chromatography and Screening for $\alpha$-Glucosidase Inhibitory Activities. Journal of Agricultural and Food Chemistry, 68(6), 1555-1562.

Preacher, K. J., \& Hayes, A. F. (2008). Asymptotic and resampling strategies for assessing and comparing indirect effects in multiple mediator models. Behavior research methods, 40(3), 879-891.

Raut, R. D., Narkhede, B., \& Gardas, B. B. (2017). To identify the critical success factors of sustainable supply chain management practices in the context of oil and gas industries: ISM approach. Renewable and Sustainable Energy Reviews, $68,33-47$.

Razzaq, S., Maqbool, N., \& Hameed, W. U. (2019). Factors Effecting The Elasticity Of Micro Credit Demand In Southern Punjab, Pakistan. International Journal of Social Sciences and Economic Review, 1(2), 46-53.

Robèrt, M. (2017). Engaging private actors in transport planning to achieve future emission targets-upscaling the Climate and Economic Research in Organisations (CERO) process to regional perspectives. Journal of Cleaner Production, 140 , 324-332.

Singsa, A., Sriyakul, T., Sutduean, J., \& Jermsittiparsert, K. (2019). Willingness of Supply Chain Employees to Support Disability Management at Workplace: A Case of Indonesian Supply Chain Companies. Journal of Computational and Theoretical Nanoscience, 16(7), 2982-2989.

Somjai, S. \& Jermsittiparsert, K. (2019). The Trade-off between Cost and Environmental Performance in the Presence of Sustainable Supply Chain. International Journal of Supply Chain Management, 8(4), 237-247.

Ul-Hameed, W., Mohammad, H., Shahar, H., Aljumah, A., \& Azizan, S. (2019). The effect of integration between audit and leadership on supply chain performance: Evidence from UK based supply chain companies. Uncertain Supply Chain Management, 7(2), 311-328.

Yadav, G., Luthra, S., Jakhar, S. K., Mangla, S. K., \& Rai, D. P. (2020). A framework to overcome sustainable supply chain challenges through solution measures of industry 4.0 and circular economy: An automotive case. Journal of Cleaner Production, 254, 120112.

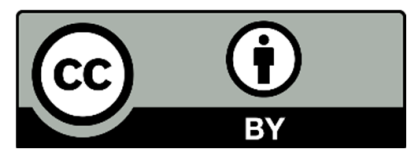

(C) 2022 by the authors; licensee Growing Science, Canada. This is an open access article distributed under the terms and conditions of the Creative Commons Attribution (CCBY) license (http://creativecommons.org/licenses/by/4.0/). 